\title{
THE FORMATION OF VOLATILE FATTY ACIDS IN THE RUMEN CONTENTS OF COWS IN VIVO AND IN VITRO
}

\author{
Martti Lampila and Ilmari PoIJÄrvi \\ Agricultural Research Centre, Department of Animal Husbandry, Tikkurila
}

Received September 11, 1959

Microbial digestion of fodder in the reticulo-rumen is responsible for a considerable part of the digestion of ruminants $(2,16)$, and so also the volatile fatty acids coming into existence as a result contribute significantly to the animals' nutrition. Since, furthermore, it has been found that these acids - owing to differences in their metabolic cycle $(12,21)$ - have mutually different effects upon the retention of balance in the carbohydrate and fat metabolism, the relative abundance of their formation has come to be of great interest in maintaining the health and productivity of the animals (e.g. 20).

The method most commonly employed in studying the relative formation of acids is determination of the acid composition of the rumen contents. It has proved useful for inter-diet comparisons, although the influence of the permeability of the rumen walls upon the resorption of acids, and thus upon the composition of the acid mixture, renders the results uncertain to some extent $(5,9,18)$. Corroboration of such results has been attempted, e.g. with the aid of culture tests.

In the investigation, part of which is presented in this paper, inter-diet comparisons with respect to acid formation were performed by using both methods in parallel. Since the $\mathrm{pH}$ of the rumen contents seems to cause variations in the rates of resorptionof the acids $(5,18)$, also the $\mathrm{pH}$ measurements were carried out so that the inferences based on the composition of the acid mixtures could be checked. In the culture tests the possibility that the $\mathrm{pH}$ level may also affect the relative formation of acids was taken into account. Therefore, cultivation was performed under $\mathrm{pH}$-controlled conditions and the $\mathrm{pH}$ of the cultures was adjusted at various levels. Moreover, attempts were made to obtain preliminary data on the escape of acids by the reticulo-omasal opening since it can be inferred that, for this part, the resorption conforms to the escaping acid quantities.

\section{Methods and results}

Acid concentrations of the rumen fluid. The experimental animals were two Ayrshire cows (live weights 559 and $564 \mathrm{~kg}$ ) with rumen fistulas. They were fed 
at 12-hour intervals. The samples were taken from the rumen in a manner described before (14). The volatile acids were distilled according to Friedemann (8) and the composition of the acid mixture was determined using the method of JAMEs and MARTIN (11) in a slightly modified form.

Table 1 shows the concentrations of the $\mathrm{C}_{2}-\mathrm{C}_{5}$ acids in the rumen fluid of one cow on a diet consisting of $5 \mathrm{~kg}$ hay, $5.3 \mathrm{~kg}$ concentrates and $30 \mathrm{~kg}$ fodder sugar beets (mangolds).

Table 1. Concentrations of volatile fatty acids (V.F.A.) in the rumen contents at various times since commencement of feeding. For details, see text. $\%=$ Molar percentage.

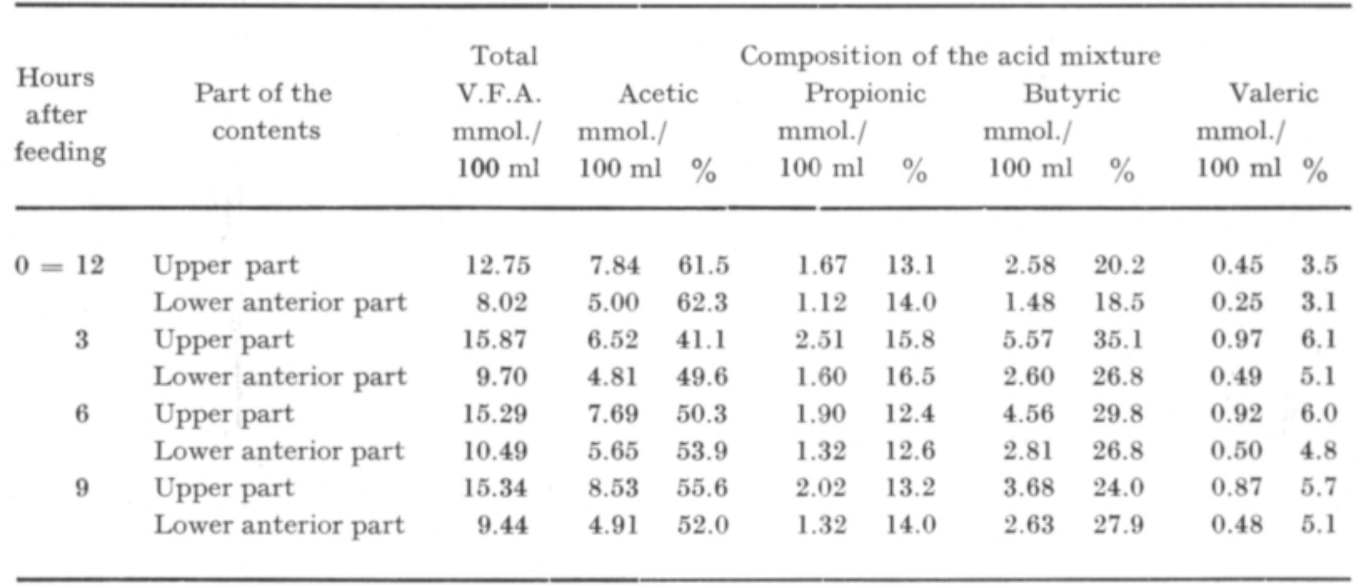

On this diet the contribution of butyric acid to the acid mixture was exceptionally high. Reports in the literature show that relative butyric acid concentrations of the same order of magnitude have occurred when ensilage with high butyric acid content was given (6) and also on diets containing exclusively or mainly concentrates $(1,4)$. A positive correlation has been found to exist between the protein content of the fodder and the butyric acid content of the acid mixture in the rumen (25) but this cannot account for the abundance of butyric acid in the present instance, which was caused by the feeding of beets, as could be concluded by comparison of the results obtained with various kinds of diet. The increasing effect of beets upon the butyric acid content was also observable in the tests with the other cow although the percentage of butyric acid did not attain an equally high level on the same diet in the latter instance.

Considering the abundance of butyric acid and the reports pointing towards its ketogenic character $(17,19)$ this result was rather unexpected in view of the fact that beets are held to be a recommendable type of fodder. On the strength of the latter argument the above circumstances would seem to be better in agreement with the results showing that a considerable part of the butyric acid falls into the realm of the carbohydrate metabolism $(13,21)$.

The contention that butyric acid is not ketogenic unless its quantity exceeds the normal level (21) evokes the question of how high this level would be. Beet 
diet appears to provide one approach for its determination. It may also be of practical value in the study of the factors affecting the fat content of the milk since the decrease of acetic acid content is mainly compensated by an increase of butyric acid. On the whole, in the variation of the content percentages, an inverse correlation has been most clearly notable in the acetic acid and propionic acid concentrations $(3,7,24)$. It is interesting to examine whether the observed difference affects the correlation that has been shown to exist between the acid composition of the rumen contents and the fat content of the milk (21).

The formation of acids in cultures. Table 2 shows the formation of acids and the influence of $\mathrm{pH}$ upon it when the rumen contents are cultivated in vitro. The fodder substance was drawn from the rumen four hours after commencement of feeding; the animal and its diet were the same to which the results in Table 1 refer. The cultivating procedure has been described before (15).

Table 2. Formation of volatile fatty acids (V.F.A.) in the rumen contents in vitro during 6 hours' incubation. For details, see text. $\%=$ Molar percentage.

\begin{tabular}{|c|c|c|c|c|c|c|c|c|c|}
\hline \multirow[t]{2}{*}{$\begin{array}{l}\mathrm{pH} \text { of the } \\
\text { culture }\end{array}$} & \multirow{2}{*}{$\begin{array}{l}\text { V.F.A. produced } \\
\text { mmol./ } \\
100 \mathrm{ml}\end{array}$} & $\begin{array}{l}\text { Ac } \\
\text { mmol./ }\end{array}$ & & $\begin{array}{r}\text { Composi } \\
\text { Proy } \\
\text { mmol./ }\end{array}$ & $\begin{array}{l}\text { n of } \\
\text { nic }\end{array}$ & $\begin{array}{r}\text { acid } \mathrm{m} \\
\text { But } \\
\text { mmol./ }\end{array}$ & $\begin{array}{l}\text { ure } p \\
\text { ic }\end{array}$ & $\begin{array}{l}\text { uced } \\
\text { Val } \\
\text { mmol./ }\end{array}$ & \\
\hline & & $100 \mathrm{ml}$ & $\%$ & $100 \mathrm{ml}$ & $\%$ & $100 \mathrm{ml}$ & $\%$ & $100 \mathrm{ml}$. & $\%$ \\
\hline 6.85 & 13.65 & 8.60 & 63.0 & 2.06 & 15.1 & 2.11 & 15.5 & 0.67 & 4.9 \\
\hline 6.00 & 12.10 & 7.11 & 58.8 & 1.38 & 11.4 & 2.95 & 24.4 & 0.79 & 6.5 \\
\hline 5.30 & 7.15 & 2.89 & 40.4 & 0.84 & 11.7 & 2.43 & 34.0 & 0.95 & 13.3 \\
\hline
\end{tabular}

The evident influence of $\mathrm{pH}$ upon the formation of acids shows that $\mathrm{pH}$ control is necessary when attempts are made to study the processes occurring in the rumen with the aid of culture tests. At the same time it gives an indication of the effect which the acidity of the rumen contents exerts upon the acid formation in vivo. However, the abundant occurrence of butyric acid in the rumen during beet diet as compared with other diets cannot be attributed to the $\mathrm{pH}$ of the rumen contents since this $\mathrm{pH}$ was not exceptional in any way. On the other hand the variation during the interval between feedings and the differences in acid composition between the different portions of the rumen contents, which were unusually great on this diet, are probably partly due to $\mathrm{pH}$.

It should be noted that the acid composition in vivo varied in the same range as that of the acid mixture which was formed in the cultures under different conditions. The $\mathrm{pH}$ variation range was approximately the same in both instances.

The transfer of acids into the omasum. The transfer of fluid into the omasum was studied with the aid of polyethylene glycol $(10,22)$. The procedure was based on the decrease of indicator concentration in the rumen contents during the interval between feedings, and it assumed that the concentration in the fluid escaping into the omasum was the same at any given moment as the average concentration in the 
reticulo-rumen. The results have been calculated per unit volume of the fluid in the rumen since the total quantity of this fluid could not be determined.

The flow was found to amount to 1.65 litres per liter of rumen fluid and 12 hours for the cow on a diet containing $5 \mathrm{~kg}$ hay and $5.3 \mathrm{~kg}$ concentrates, while the figure of 2.0 litres was obtained for the cow on a diet richer in concentrates by $4 \mathrm{~kg}$. Parallel tests gave respectively identical results in both instances. The indicator concentration decreased most strongly in the first half of the interval between feedings, deviating from the theoretical dilution curve. It is conceivable that the quantity of fluid in the rumen increased at the same time. In the calculations, however, this quantity was assumed to remain constant.

Assuming the quantity of fluid in the rumen to be 60 litres, the daily flow quantity will be 198 and 240 litres, respectively. These figures are high in comparison with the corresponding results (140-170 litres) of SPERBER et al. (23) but they maybe explainable if one takes into account that the rumen contents may be augmented by water entering the rumen - except as drinking water and with saliva - also by secretion through the rumen walls (5). However, the possibility should also be kept in mind that the microbial flora may decompose the polyethylen glycol to some extent. Since its concentrations were fairly low, such decomposition may perhaps have affected the results.

The mean concentrations of volatile fatty acids in the samples taken from the lower anterior part of the rumen, close to the opening into the recitulum, were 96 and $90 \mathrm{mmol} / \mathrm{litre}$, respectively. If they are taken to represent the mean concentrations of the fluid escaping into the omasum, the acid quantities entering the omasum in 24 hours will have been 18.8 and $21.6 \mathrm{~mol}$, respectively. These values, which are subject to the aforesaid reservations and have to be considered primarily as showing the order of magnitude, point to the fact that the share of the acid quantities escaping into the omasum in the escape of acids from the rumen is worthy of serious notice.

Acknowledgement. The authors wish to express their respectful gratitude to the State Committee of Science for the grant which has enabled them to conduct this investigation.

\section{Sum $m$ ary}

On a diet containing fodder sugar beets the proportion of butyric acid in the mixture of the volatile fatty acids of the rumen contents was found to be unusually high.

When the rumen contents were incubated at different $\mathrm{pH}$-levels in vitro, it was found that the proportion of butyric acid in the volatile fatty acid mixture produced increases when the $\mathrm{pH}$ decreases.

Using polyethylene glycol as a reference substance, the transfer of fluid through the reticulo-omasal orifice was studied. The transfer of volatile fatty acids into the omasum is calculated on the basis of the fluid flow and on the acid concentrations of the fluid in the lower anterior part of the contents. 
(1) Annison, E. F. 1954. Some observations on volatile fatty acids in the sheep's rumen. Biochem. J. 57: $400-405$.

(2) Balch, C. C., Balch, D. A., Bartlett, S., Bartrum, M. P., Johnson, V. W., Rowland, S. J. \& TURner, J. 1955. Studies on the secretion of milk of low fat content by cows on diets low in hay and high in concentrates. VI. The effect on the physical and biochemical processes of the reticulo-rumen. J. Dairy Res. 22: $270-289$.

(3) Balch, D. A. \& Rowland, S. J. 1957. Volatile fatty acids and lactic acid in the rumen of dairy cows receiving a variety of diets. Brit. J. Nutrition 11: 288-298.

(4) Card, C. S. \& Schultz, L. H. 1953. Effect of the ration on volatile fatty acid production in the rumen. Ibid. 36: 599, P91.

(5) Danielli, J. F., Hitchсоск, M. W. S., Marshall, R. A. \& Phillipson, A. T. 1945. The mechanism of absorbtion from the rumen as exemplified by the behaviour of acetic, propionic and butyric acids. J. Exp. Biol. 22: 75-84.

(6) Elliot, J. M., Bennetr, E. \& Archibald, J. G. 1957. Effect of feeding certain silages on the relative concentrations of rumen volatile fatty acids. J. Dairy Sci. 40: 356-362.

(7) El-Shazly, K. 1952. Degradation of protein in the rumen of the sheep. 1. Some volatile fatty acids, including branched-chain isomers, found in vivo. Biochem. J. 51:640-647.

(8) Friedemann, T. E. 1938. The identification and quantitative determination of volatile alcohols and acids. J. Biol. Chem. 123: 161-184.

(9) Gray, F. V. 1947. The absorption of volatile fatty acids from the rumen. J. Exp. Biol. 24: 1-10.

(10) HYDÉN, S. 1956. A turbidimetric method for the determination of higher polyethylene glycols in biological materials. Ann. Roy. Agr. Coll. Sweden 22: 139-145.

(11) James, A. T. \& Martin, A. J. P. 1952. Gas-liquid partition chromatography: the separation and micro-estimation of volatile fatty acids from formic acid to dodecanoic acid. Biochem. $\mathrm{J}$. 50: $679-690$.

(12) Klember, M. 1956. Ernährungsforschung an intakten Kûhen mit Hilfe von Isotopen als Tracern. Ztschr. Tierernähr. Futtermittelk. 11: 195-219.

(13) - - Black, A. L., Brown, M. A., Luick, J., Baxter, C. F. \& Tolbert, B. M. 1954. Butyrate as a precursor of milk constituents in the intact dairy cow. J. Biol. Chem. 210: 239-247.

(14) Lampila, M. 1955. Preliminary studies on the variations of $\mathrm{pH}$ and volatile fatty acid concentration of the rumen contents of the cow. J. Sci. Agr. Soc. Finland 27: 142-153.

(15) $\rightarrow$ 1959. On the effect of $\mathrm{pH}$ in vitro upon the microbial processes in the rumen contents of the cow. Acta Agr. Fenn. in Press.

(16) Palohermo, L., MäkelẌ, A. \& SAlo, M.-L. 1955. Some quantitative data on the role of the ruminant proventriculi in the digestion and absorption of nitrogen-free organic matter. J. Sci. Agr. Soc. Finland 27: 70-76.

(17) Pennington, R. J. 1952. The metabolism of short-chain fatty acids in the sheep. 1. Fatty acid utilization and ketone body production by rumen epithelium and other tissues. Biochem. J. 51: $251-258$.

(18) Pfander, W. H. \& Phillipson, A. T. 1953. The rates of absorbtion of acetic, propionic and n-butyric acids. J. Physiol. 122: 102-110.

(19) Schultz, L. H. \& Sмrтн, V. R. 1951. Experimental alteration of the sugar and ketone levels of the blood of ruminants in relation to ketosis. J. Dairy Sci. 34: 1191-1199.

(20) Sнaw, J. C. 1956. Ketosis in dairy cattle. A review. Ibid. 39: 402-434.

(21) - Lakshmanan, S., Chung, A. C., Leffel, E. C. \& Doetsch, R. N. 1958. Intermediary metabolism in the ruminant including studies on rumen, liver and lactating udder. 2nd U.N. Intern. Conf. Peaceful Uses Atomic En. A/Conf. 15/P/813, U.S.A. June 1958: 1-15.

(22) Sperber, I., Hyden, S. \& Ekman, J. 1953. The use of polyethylene glycol as a reference substance in the study of ruminant digestion. Ann. Agr. Coll. Sweden 20: 337-344.

(23) $\rightarrow$ 1956. Studies in ruminent digestion. Contribution to VIIth Internat. Congr. Animal Husbandry. Madrid, May 23-June 1., pp. 113-136. 
(24) TYZnik, W. \& Allen, N. N. 1951. The relation of roughage intake to the fat content of the milk and the level of fatty acids in the rumen. J. Dairy Sci. 34: 493, P19.

(25) Woodhouse, N .S., Davis, R. F. \& Becк, G. H. 1955. The effect of protein level on rumen volatile fatty acids. Ibid. $38: 605-606, \mathrm{P} 23$.

S E L O S T S :

\section{HAIHTUVIEN RASVAHAPPOJEN MUODOSTUMISESTA LEHMÄN PÖTSIN SISÄLLOSSÄ IN VIVO JA IN VITRO}

Marti Lampila ja Ilmari Poijärvi

Maatalouden tutkimuskeskus, kotieläinhoidon tutkimuslaitos, Tikkurila

Kirjoituksessa on esitetty tuloksia kokeista, joilla pyrittiin selvittämään lehmän pötsissä eri dieettien aikana tapahtuvaa haihtuvien rasvahappojen muodostumista. Sanotušsa tarkoituksessa määritettiin analyyttisesti pötsinesteen haihtuvien happojen pitoisuudet ja niiden vaihtelut, selvitettiin happojen muodostumista in vitro-kokein ja hankittiin alustavia tietoja siitä, paljonko happoja poistuu pötsistä verkkomaha-satakerta-aukon kautta.

Tulokset osoittavat rehusokerijuurikkailla olleen selvän pötsinesteen voihappopitoisuutta kohottavan vaikutuksen. Kun dieetti sisälsi niitä $30 \mathrm{~kg}$, kohosi voihapon mooliprosenttinen osuus happoseoksessa toisen pötsifistelillä varustetun koelehmän pötsinsisällön yläosassa 20.2:sta 35.1:een kolmen tunnin kuluessa ruokinnan alusta lukien. Samalla aleni etikkahapon osuus 61.5:stä 41.1:een prosenttiin.

Kun pötsistä otettua rehumassaa inkuboitiin säätäen sen $\mathrm{pH}$ eri tasoille pötsissä normaalisti esiintyvän vaihtelun rajoissa, havaittiin, että pH-muutokset vaikuttavat suhteellisesti eri tavoin eri happojen muodostumisnopeuteen. Se ilmeni siten, että $\mathrm{pH}: \mathrm{n}$ alentuessa voi- ja valeriaanahapon osuus muodostuneessa happoseoksessa kohosi ja etikkahapon osuus aleni.

Nesteen kulku verkkomaha—satakerta-aukon kautta, määritettynä vesiliukoisen indikaattoriaineen (polyetylenglykolin) avulla, oli toisella koelehmällä 1.651 ja toisella 2.01 jokaista pötsinsisällön nestelitraa kohti 12-tuntisen ruokintavälin aikana. Viimemainitun lehmän dieetti sisälsi văkirehua 4 kg enemmän. Haihtuvien happojen keskimääräiset pitoisuudet pötsin etu-alaosasta otetuissa näytteissä, joiden oletettiin edustavan poistuvan liuoksen konsentraatioita, olivat vastaavasti 96 ja 90 mmol./1. Koska nestekulkua esittävät luvut ovat huomattavan suuret, on tehty varaus, että indikaattoriaineen mahdollinen hajoaminen on voinut vaikuttaa niihin. 